\title{
CASAMENTOS INVERTIDOS: ACUSAÇÕES E PRECONCEITOS EM ARRANJOS CONJUGAIS DESVIANTES*
}

Por que determinados homens se casam com mulheres mais velhas? Por que algumas mulheres escolhem homens mais jovens? Quais são os principais capitais desses arranjos conjugais? Quais os estigmas e preconceitos existentes? Qual a visão dos outros sobre esses relacionamentos?

Neste artigo busco analisar os discursos femininos e masculinos sobre casamentos nos quais as mulheres são mais velhas que seus maridos. Utilizo como base para reflexão os dados da pesquisa "Corpo, envelhecimento e felicidade" (Goldenberg, 20II), os resultados de dois grupos focais: o primeiro, com doze mulheres casadas com homens mais novos; o segundo, com dez homens casados com mulheres mais velhas. Após a análise dos grupos, foram realizadas nove entrevistas em profundidade, cinco com homens e quatro com mulheres. Trabalhei com casais que estão juntos há, no mínimo, dez anos; as mulheres são, pelo menos, dez anos mais velhas que seus maridos.

Todas as pesquisadas já foram casadas anteriormente, têm filhos de casamentos anteriores (em muitos casos, os filhos são da mesma idade do atual marido), têm nível universitário e são moradoras da Zona Sul do Rio de Janeiro; são advogadas, administradoras de empresa, psicólogas, farmacêuticas, fisioterapeutas.

Os homens pesquisados estão em seu primeiro casamento, não têm filhos e têm nível universitário. São economistas, administradores de empresa, atores, arquitetos, professores, policiais militares. Antes de se casarem, 
ainda não tinham cursado a universidade e moravam na Zona Norte, ou em subúrbios da cidade do Rio de Janeiro.

Se o corpo (jovem) é um capital, por que alguns homens preferem as mulheres mais velhas? Se o casamento com homens mais novos é algo desviante na nossa cultura, por que algumas mulheres preferem maridos mais jovens?

\section{O CORPO (JOVEM) COMO CAPITAL}

Nas últimas duas décadas, ao pesquisar homens e mulheres da classe média da cidade do Rio de Janeiro, tenho sido constantemente surpreendida pela frequência com que a categoria "o corpo" está presente no discurso dos meus interlocutores. É importante reconhecer que não é possível generalizar a ideia de que "o corpo" é um importante valor na cultura brasileira como um todo. Essa ideia está presente de uma forma muito mais forte em um determinado segmento da classe média brasileira e, em particular, entre os moradores da cidade do Rio de Janeiro.

Este é um segmento social que pode ser descrito como predominantemente branco, heterossexual, com nível universitário, com uma renda alta, moradores da Zona Sul do Rio de Janeiro e, especialmente, nos bairros mais nobres da cidade (Leblon, Ipanema, Gávea, Lagoa, Jardim Botânico, Botafogo, Copacabana, Humaitá). Esses indivíduos constituem uma elite econômica, intelectual, política e cultural no Brasil; têm poder material e simbólico e podem, consequentemente, construir e reproduzir corpos que são socialmente legitimados como hegemônicos.

Os homens e mulheres das classes médias que tenho pesquisado podem ser considerados uma vanguarda para inúmeros brasileiros, pois os seus comportamentos, discursos e corpos são valorizados e reproduzidos por outros segmentos da população. Este grupo está composto de corpos que são desejados, admirados, invejados e imitados por outros, corpos e comportamentos que são constantemente retratados como normativos na mídia e, especialmente, nas telenovelas, programas de televisão, propagandas etc.

A visão de mundo e o modo de vida desse segmento social têm um efeito multiplicador que vai muito além de seus limites de classe, o que sugere que ele pode ser útil para revelar, em termos mais amplos, as transformações experimentadas pela sociedade brasileira. Não se pode dizer, no entanto, que o universo por mim pesquisado possui "corpos brasileiros típicos". Mas é possível afirmar que "o corpo" apresentado por este grupo é, de longe, "o corpo" mais imitado pelos brasileiros em geral e, especialmente, por mulheres brasileiras.

Como afirmou Marcel Mauss (I974), é por meio da "imitação prestigiosa" que os indivíduos de cada cultura constroem seus corpos e comportamentos. Para Mauss, o conjunto de hábitos, costumes, crenças e tradições que caracterizam uma cultura também se refere ao corpo. Assim, há uma cons- 
trução cultural do corpo, com uma valorização de certos atributos e comportamentos em detrimento de outros, fazendo com que haja um corpo típico para cada sociedade. Esse corpo, que pode variar de acordo com o contexto histórico e cultural, é adquirido pelos membros da sociedade por meio da "imitação prestigiosa". Os indivíduos imitam atos, comportamentos e corpos que obtiveram êxito e que têm prestígio em sua cultura. É importante destacar que este processo de imitação não é, necessariamente, um ato consciente dos membros de cada cultura.

Iniciei essa reflexão no livro $\mathrm{Nu} \&$ vestido (2002), ao analisar I.279 questionários, respondidos por 835 mulheres e 444 homens, de 17 a 50 anos, com nível universitário, renda superior a US\$ 2 mil, moradores da cidade do Rio de Janeiro. Focalizando as relações de gênero, busquei compreender as expectativas, desejos afetivos e estereótipos sexuais de homens e mulheres de diferentes gerações. Desde 1988 realizo pesquisas que têm como foco as novas conjugalidades, a sexualidade, a infidelidade e a construção social do corpo na cultura brasileira.

No presente texto procuro retomar os temas sobre os quais tenho refletido ao longo desses anos por meio de um novo caminho metodológico e com novas questões, surgidas a partir das transformações nos papéis de gênero. Com a preocupação de ampliar o espectro de meus estudos desenvolvidos anteriormente por meio de entrevistas em profundidade e observação participante, análise de trajetórias e reportagens da mídia, elaborei um roteiro de questões para serem trabalhadas em grupos focais e entrevistas em profundidade, focalizando as representações sobre ser homem e ser mulher, os modelos ideais de casamento, as diferentes experiências de relacionamentos afetivos e sexuais, buscando compreender o arranjo conjugal entre uma mulher mais velha e um homem mais jovem.

\section{O TABU DA IDADE: REALIDADE E FICÇÃO}

O Washington Post de 8 de junho de 2009 afirmou que o Brasil é o segundo país onde as pessoas mais assistem à televisão, perdendo apenas para a Grã-Bretanha. As telenovelas, de acordo com o jornal, têm uma influência decisiva nas escolhas do estilo de vida dos brasileiros. É realmente difícil pensar o Brasil contemporâneo sem analisar a influência das telenovelas.

A matéria mostra estudos do Banco Interamericano de Desenvolvimento (BID) que demonstram a relação entre o consumo das telenovelas da Rede Globo, a maior do país, e o declínio nas taxas de fertilidade e o crescimento das taxas de divórcio no país. A taxa de fertilidade no Brasil caiu vertiginosamente nos últimos cinquenta anos, de mais de seis filhos por família, em I960, para menos de dois no início do século XXI, observa o estudo. Esta queda é comparável à da China, mas sem quaisquer medidas de planejamento familiar. 
A análise de II5 novelas da Rede Globo entre I965 e I999 mostrou que $72 \%$ das protagonistas femininas não tinha filhos, que e $21 \%$ tinha apenas um filho. As novelas mostravam a pequena, branca, saudável e urbana família consumista de classe média e média alta. As novelas, no Brasil, se tornaram um meio poderoso através do qual a família e os relacionamentos afetivos e sexuais foram idealizados. Os novos arranjos conjugais, que invertem a lógica dominante, têm estado muito presentes nas novelas. Em quase todas, mulheres mais velhas se apaixonam por homens jovens, e vice-versa.

No caso brasileiro, muitas das mulheres mais bem-sucedidas, ricas e famosas, as mulheres "imitáveis", são atrizes das telenovelas da Rede Globo, especialmente aquelas que são protagonistas das novelas exibidas no chamado "horário nobre". Mas, também, são objeto de imitação as modelos, cantoras e apresentadoras de televisão, todas elas tendo "o corpo (jovem)" como o seu principal capital, ou uma de suas mais importantes riquezas.

Os corpos e os comportamentos mais imitados na cultura brasileira estão, sem dúvida alguma, nas telenovelas da Rede Globo. Elas podem ser vistas como um reflexo dos corpos e comportamentos existentes na sociedade, mas, ao mesmo tempo, mostram inovações comportamentais e novos estilos de vida. As tramas das novelas da Rede Globo ganham destaque nas capas das principais revistas e jornais brasileiros. Inúmeras telenovelas exploraram situações polêmicas e provocaram discussões em todas as regiões do país, misturando ficção e realidade. Roupas, acessórios, cortes de cabelo, esmaltes, móveis, são imitados por mulheres e homens que assistem às novelas. Mais ainda, comportamentos e estilos de vida também se transformam quando veiculados pelas telenovelas da Rede Globo.

Mulheres mais velhas casadas com homens mais jovens é um tema recorrente nas telenovelas, filmes, romances, colunas de fofocas etc. Provoca o olhar de censura, o sentimento de repulsa e, talvez, o de inveja; são relacionamentos considerados proibidos, reprováveis ou inaceitáveis em nossa cultura.

Para mostrar que este tipo de relacionamento não é algo novo entre nós, é interessante lembrar, antes de iniciar a reflexão sobre o grupo pesquisado, o caso de Chiquinha Gonzaga, compositora, pianista e primeira mulher a reger uma orquestra no Brasil. Ela nasceu em 1847 e teve quatro filhos. Aos 52 anos, conheceu João Batista, de 16 anos, um aprendiz de música. Apaixonaram-se e viveram juntos até o dia em que ela morreu, em I935, aos 87 anos. Temendo o preconceito, Chiquinha dizia que João Batista era seu filho adotivo e muitos só descobriram o romance depois de sua morte.

Ainda pensando no conceito de "imitação prestigiosa", algumas das mulheres mais famosas do Brasil são ou foram casadas com homens mais jovens. A revista Veja (I4/5/2010) apontou casos famosos de mulheres casadas com homens mais jovens, como a apresentadora Ana Maria Braga, ${ }^{\mathrm{I}}$ casada com um homem 22 anos mais jovem; a cantora Elba Ramalho, que estava 
namorando um rapaz 33 anos mais jovem; a apresentadora Marília Gabriela que, durante oito anos, foi namorada do ator Reynaldo Gianecchini, 25 anos mais jovem que ela; a atriz Susana Vieira, ${ }^{2}$ casada com um mágico e ator $4 \mathrm{I}$ anos mais jovem, e a cantora Elza Soares, casada com um homem 46 anos mais jovem que ela.

É interessante destacar que duas das mulheres famosas que aparecem na matéria da revista Veja, Susana Vieira e Elza Soares, foram as mais citadas na minha pesquisa quando pedi: "dê um exemplo de uma pessoa famosa que envelheceu mal". As duas apareceram em primeiro lugar, por não "aceitarem o envelhecimento" e "se comportarem de forma inadequada para a idade". Nos dois casos, o fato de terem relacionamentos com homens muito mais jovens é muito criticado. Elza Soares também é extremamente criticada em função do excesso de cirurgias plásticas.

A ênfase dos pesquisados é a de que, por não aceitarem a idade, as duas se comportam de forma inapropriada: namoram homens mais jovens, usam roupas inadequadas para a idade e fazem um excesso de cirurgias plásticas.

Outro exemplo de mau envelhecimento citado nas respostas dos pesquisados é o da atriz Vera Fischer. Ela aparece por não aceitar a idade, por namorar homens mais jovens, pelo uso de botox, pelas cirurgias plásticas e, também pelo vício em drogas e álcool. Eles dizem: "ela é barraqueira", "está sempre metida em brigas e confusões". Seu comportamento é considerado totalmente inapropriado para uma mulher de mais de 60 anos (ela nasceu em I95I).

Em I987, quando protagonizou a novela "Mandala", Vera Fischer conheceu e se apaixonou pelo ator Felipe Camargo, quase dez anos mais jovem do que ela. Ela era Jocasta e ele, Édipo, seu filho.

A novela "Mandala" trouxe para o Rio de Janeiro do século XX o mito da tragédia Édipo Rei, de Sófocles, trama de Dias Gomes e Marcílio Moraes, que abordava temas polêmicos como o incesto e uso de drogas.

Jocasta, uma estudante de sociologia, tem um romance com Laio, um rapaz rico e ambicioso. Ela fica grávida e o futuro pai consulta um guru que diz que seu destino é ser morto pelo próprio filho, que se casará com Jocasta. Laio planeja o sequestro do filho, que é recolhido e criado por um casal. Mais tarde, sem saber que são mãe e filho, Jocasta e Édipo se apaixonam. Mas o caso provocou tanta polêmica que acabou se limitando a um único beijo dos dois na novela.

Vera Fischer voltou ao estrelato em 2000, em "Laços de Família", de Manoel Carlos. Na novela, era Helena, a protagonista, que se apaixona e troca beijos ardentes com o personagem de Reynaldo Gianecchini, com 27 anos na época. Gianecchini, na vida real, namorava a apresentadora Marília Gabriela (também citada na matéria da Veja), 25 anos mais velha que ele. As notícias exploraram a coincidência da vida real com a novela: ambas loiras e muito mais velhas disputando o amor de um galã iniciante, o que garantiu, por várias semanas, uma boa divulgação para "Laços de Família". 
O autor, Manoel Carlos, afirmou inúmeras vezes que o papel de Helena tinha sido escrito especialmente para Vera Fischer:

Eu fiz a Helena para a Vera Fischer. Precisava de uma mulher que aparentasse uns 45 anos [na vida real ela estava com 50 anos] que tanto possa apaixonar um rapaz de 20 anos como um de 50, 60. Por isso, eu disse para a Marluce [diretora-geral da Globo]: "se a Vera Fischer não puder fazer a novela, eu não faço essa novela. Porque essa história eu só faço com ela”, contou Manoel Carlos à Folha de S. Paulo (I I/3/200I).

Na novela, a filha de Helena, Camila, personagem da jovem atriz Carolina Dieckmann, também se apaixona pelo galã interpretado por Gianecchini: mãe e filha amam o mesmo homem.

Os romances e casamentos de mulheres mais velhas com homens mais jovens têm sido explorados em muitas telenovelas recentes. A frequência com que nos deparamos com o tema do relacionamento da mulher mais velha com um homem que poderia ser seu filho ou namorado de sua filha, não só nas novelas, revistas e jornais, mas, também, em debates acalorados, demonstra que estamos diante de um verdadeiro tabu.

No entanto, alguns casos de mulheres famosas casadas com homens mais jovens aparecem pouco na mídia e parecem não provocar qualquer polêmica. Um destes casos discretos é o da atriz Marília Pêra, ${ }^{3}$ de 7 I anos, que está casada há I6 com um economista 2I anos mais jovem. Em matéria com o título "O amor não tem idade", ela disse que nunca foi criticada ou foi alvo de comentários maldosos por estar ao lado de um homem mais novo: "Comigo, nunca houve preconceito. A minha mãe adora ele, meus filhos também, e sou amicíssima da mãe dele. As pessoas que me importariam a opinião se manifestaram sempre de forma favorável".

No entanto, ela parece se defender de qualquer possível acusação de desvio quando afirma que algum tipo de interesse sempre existe em qualquer relação de amor: "Pode haver jogo de interesse numa relação de duas pessoas muito jovens, não tem a ver com a idade. Mas qualquer relação, seja ela de amor ou de paixão, é uma relação de interesse. O amor de uma mãe por um filho é muitas vezes interesseiro. A necessidade de se estar junto tem, no mínimo, o interesse porque o outro traz o benefício de se sentir bem".

Marília Pêra disse ainda que os $2 \mathrm{I}$ anos a mais não fazem a menor diferença: "Olho para ele e o vejo com a minha idade. Não sei se vejo ele velho ou se me vejo jovem. Além disso, ele parece mais velho, é muito educado, não é um garotão, é um senhor, conservador, formal".

\section{DOMINAÇÃO MASCULINA E MERCADO MATRIMONIAL}

Pierre Bourdieu, em A dominação masculina, afirma que a maior parte das mulheres francesas deseja ter um cônjuge mais velho e mais alto que elas. $\mathrm{O}$ 
autor mostra que elas se sentem diminuídas se o parceiro é menor ou mais jovem. Portanto, "elas só podem querer e amar um homem cuja dignidade esteja claramente afirmada e atestada no fato, e pelo fato, de que 'ele as supera' visivelmente" (Bourdieu, 2010: 48).

A demógrafa Elza Berquó (I998) afirma que o fato de os homens se casarem com mulheres mais jovens é uma constante praticamente universal e deve-se à relação de poder entre os sexos. Embora em alguns contextos as relações de gênero venham se tornando menos assimétricas, não tiveram ainda impacto visível na diferença entre as idades de homens e mulheres ao se casarem.

Berquó diz que são raros os estudos sobre outras moedas de troca, além da juventude, oferecidas pelas mulheres e aceitas pelos homens no mercado matrimonial. A persistência da diferença de idade, no caso brasileiro, que conta com um superávit de mulheres em todas as faixas etárias a partir dos I5 anos, tem consequências diretas no celibato feminino e no expressivo segmento de mulheres separadas ou viúvas com poucas chances de casamento.

A desvantagem das brasileiras no mercado matrimonial é gritante. A situação se torna cada vez mais assimétrica à medida que homens e mulheres avançam na idade: com o envelhecimento, as chances de casamento diminuem para as mulheres e aumentam para os homens.

Berquó mostra que a norma social segundo a qual o homem deve se casar com uma mulher mais jovem contribui muito para a existência do que ela chamou de pirâmide da solidão. Além disso, a tendência dos homens que se separam é a de se recasarem com mulheres ainda mais jovens. Berquó acredita que, em uma sociedade em que impera a cultura do corpo e da juventude, é muito pouco provável que um número expressivo de mulheres se relacione com um homem muito mais jovem, não só porque esses jovens não se interessariam por elas, mas, principalmente, porque as mulheres mais velhas se sentiriam inseguras e ameaçadas com as marcas do envelhecimento, ainda mais ao competirem com mulheres mais jovens pelos mesmos homens.

Em função dos preconceitos existentes, as brasileiras olham para as faixas etárias acima de sua idade ao procurar um parceiro amoroso. Já os homens olham para baixo, em busca de uma parceira mais jovem que ele. Portanto, a existência de um tabu da idade limita as chances de uma brasileira casar-se ou recasar-se quando está mais velha.

No entanto, a realidade do mercado matrimonial está mudando e cada vez mais mulheres estão olhando para faixas etárias mais baixas ao procurar um parceiro amoroso.

O Instituto Brasileiro de Geografia e Estatística (IBGE) mostra que cresceram as uniões em que as mulheres têm idade superior à do homem. Segundo a Pesquisa Nacional por Amostra de Domicílios (PNAD), de I996 a 2006, essas uniões passaram de 5,6 milhões para 7,6 milhões, o que representa um 
crescimento de $36 \%$. E continuam crescendo. Na maioria dos casos em que a mulher é mais velha que o parceiro, a diferença de idade costuma ser pequena. De acordo com a PNAD, dos 7,6 milhões de casais nessa situação, 64,7\%, ou 4,9 milhões, são formados por cônjuges que têm de i a 4 anos de diferença. Outros I,75 milhão, ou $23,2 \%$, têm de 5 a 9 anos. O terceiro grupo é o que apresenta de ıо a I4 anos de diferença: $592 \mathrm{mil}$, ou 7,7\% do total. No período analisado, o número de famílias em que a mulher vive com alguém mais de dez anos mais jovem aumentou 59,5\%: de 585 mil para 927 mil.

A pesquisa revela ainda que famílias em que a mulher é mais velha e trabalha fora subvertem a regra de que é sempre o homem que ganha mais. A PNAD mostra que o diferencial de rendimento entre o casal aumenta conforme avança a diferença de idade. Homens casados com mulheres 30 anos mais velhas ganham, em média, $25 \%$ do que elas ganham. Isso acontece porque uma mulher madura e com décadas de carreira pode já ter alcançado um nível de reconhecimento profissional que um rapaz jovem ainda não atingiu. Ao analisar a escolaridade média dos casais, o estudo revelou que a mulher, nestes casos, tem geralmente I,4 ano de estudo a mais que seu parceiro. $O$ que explicaria o crescimento deste tipo de arranjo conjugal?

\section{O DISCURSO MASCULINO: ELA É ESPECIAL}

Ao analisar a lógica dos discursos masculinos, é fácil perceber que a ênfase está colocada na distinção de suas esposas com relação às outras mulheres. Para eles, elas são mais carinhosas, mais generosas e mais alegres que as mulheres mais jovens. São também mais animadas, mais positivas e mais jovens de comportamento que eles.

É muito interessante observar, nos depoimentos masculinos, uma certa estrutura do discurso sobre a escolha amorosa. É possível constatar que, para eles, as esposas não são mulheres quaisquer, cujo principal diferencial das demais é serem mais velhas. Elas têm certas características em comum que as tornam especiais, características que podem ser explicadas pelo fato de serem mais velhas, mas que não estão diretamente vinculadas à idade.

Um fato é importante destacar: os pesquisados não têm o que poderíamos chamar de uma carreira de escolha desviante em seus relacionamentos anteriores, isto é, não são homens que sempre se relacionaram com mulheres mais velhas. Eles insistem em dizer que, antes delas, sempre se relacionaram com mulheres mais jovens que eles. Então, por que agora escolheram mulheres mais velhas? As respostas masculinas se concentram em três principais características: I) Ela é cuidadora; 2) Ela é jovem de espírito; 3) Ela é superior. 


\section{ELA É CUIDADORA}

Os pesquisados destacam o cuidado como a principal característica de suas mulheres. Elas são extremamente disponíveis, atenciosas e dedicadas não só com eles, mas, também, com os filhos, amigos, familiares, pais, vizinhos, colegas de trabalho etc. São mulheres que resolvem os problemas de todo mundo, que são o centro do cuidado das famílias como um todo, especialmente dos filhos e netos, e que são muito procuradas para resolver problemas e dar conselhos para amigos e familiares. Eles demonstram ter muito ciúmes da atenção e do tempo que elas dedicam aos "outros", afirmando querer ter mais tempo e atenção "para si". o cuidado, traduzido no carinho, atenção, disponibilidade e dedicação delas para com eles pode ser apontando como o mais importante capital dessas relações.

Diana Neves (20II) ressalta que, para os pesquisados, as mulheres mais velhas são diferentes das mais jovens pela capacidade de acolhimento e de orientação, traduzida em palavras como, por exemplo: porto seguro, paz, colo, orientação, sabedoria, vivência, bálsamo, segurança, apoio, compreensão, seriedade, ajuda, base, confiança, amizade, calma, parceria, companheirismo, cumplicidade e, especialmente, cuidado, carinho, atenção, experiência e maturidade. "Eu não sei se eu vou ter suporte para ser o porto seguro na vida de alguém, acostumado com uma mulher dessas, com esse colo, não que eu seja dependente, mas para tudo ela tem sempre um caminho para fazer o melhor". (R 36, esposa 56 )

Neves destaca que os pesquisados identificam uma transformação positiva em suas vidas depois do encontro com suas esposas, nos moldes da fórmula "antes e depois". Eles dizem que: "Ela me ensinou a ser mais solto e social"; "eu fiquei muito mais responsável, fiquei muito mais focado na minha carreira profissional"; "ela mudou a minha vida"; "ela salvou a minha vida".

Eu tirei um tumor, estávamos só seis meses juntos. Ela largou tudo, emprego, para ficar comigo. Dizia: "do jeito que ele sair, ele é meu, quem vai cuidar dele sou eu". Ela ganhava bem, jogou tudo para o alto para ficar comigo. Isso foi um presente de Deus (R 36, esposa 56).

Eu era muito louco, eu tinha moto, andava com uma galera que era meio maluca e era muito namorador. Ela me tirou de muita furada, eu andava de moto cheio de álcool, caí de moto, fiquei internado, seis meses sem andar. Hoje eu não saio de casa. Ela manda eu ir para a praia, eu compro a cervejinha e fico em casa, talvez por eu ter passado pelo lance de quase chegar à morte (A 34, esposa 56$)$.

Tais mudanças não parecem ter sido resultado de cobranças delas, como afirma Neves. Eles enxergam em suas esposas qualidades como experiência, sabedoria, apoio e orientação. Para a autora, é possível que eles tenham se sentido estimulados a mudar, talvez para se tornarem pessoas melhores para elas. 
Ela me deixou livre: "no dia que você tiver que se ajeitar, você vai se ajeitar", e as coisas foram mudando, eu senti vontade de querer construir alguma coisa, porque o apoio foi ficando mais forte. Mulher nova na rua chama a atenção, eu vou olhar porque eu sou homem, ela passa rebolando, mas eu penso no apoio que a minha esposa me dá. Eu era muito de farra, muito de beber, de escancarar, de me envolver com gente que não presta, ela foi conversando comigo, em momento algum impôs nada. (H 31, esposa 42)

\section{ELA É JOVEM DE ESPÍRITO}

Muitos pesquisados têm a mesma idade dos filhos das esposas e, mais ainda, são chamados de filhos por elas. "A minha mulher é tão atenciosa que se eu ligar para ela vir me buscar, ela vem me buscar. Ela me chama de filho" (E 40, esposa 56).

Eles procuram enfatizar que não é uma relação maternal, mas de homem-mulher, e que reagem quando os outros acham que são filhos de suas esposas.

Eu já ouvi, no shopping, a minha esposa escolhendo uma sandália, a garota falou: "aquela senhora está escolhendo uma sandália para o filho dela". Eu dei um beijo nela na hora, para elas saberem que eu era o marido (E 40, esposa 56).

Hoje o pessoal acostumou, antigamente perguntava: "seu filho?" Ela ficava constrangida, eu não, eu não esquentava, dizia: "eu sou o filho mais velho dela", brincando, aí dava um beijo na boca dela (A 34, esposa 56).

Todos os pesquisados dizem que são, na realidade, mais velhos que as esposas. Elas são "jovens de espírito": são extrovertidas, animadas, divertidas, cheias de energia, gostam de sair, dançar, passear, enquanto eles preferem ficar em casa, vendo televisão ou tomando uma cerveja.

O que mais gosto é o jeito dela de ser alegre, ela te deixa para o alto, qualquer coisa ela está na brincadeira. Eu que sou mais quieto, ela participa de tudo. Ela tem o espírito jovem, mais do que o meu, porque eu sou mais velho, eu tenho a cabeça mais velha que ela. Ela é mais alegre (A 34, esposa 56).

Os pesquisados disseram que as mulheres se preocupam muito mais com a idade e com a aparência do que eles.

A minha esposa está em período de depressão, o corpo está legal, porque malha, mas os sinais do rosto não adianta esconder muito. Ela questiona toda hora: "você vai me querer quando eu tiver 65 ?" ... "Lógico, você vai continuar a gatinha de sempre". Ela tem uma mania quando a gente transa de perguntar se quero que apague a luz. Não precisa, eu gosto de luz, se tiver espelho até melhor (E 40, esposa 56).

Ela tenta até esconder algumas coisas. Eu não ligo, mas você sente que ela está meio tensa, e ela pede para eu jogar limpo: "quando você não sentir atração por mim, me fala que eu vou entender" (J 25, esposa 41). 
Eles parecem não enxergar ou, melhor, não dar importância aos sinais da idade ou defeitos de suas mulheres.

Às vezes eu percebo nela receio, ela fala que está ficando velha, só que eu não vejo isso, eu vejo a essência dela, não vejo pele, se está mole, para mim está tudo perfeito. Eu não vejo defeito, mas sinto a preocupação nela, que daqui a pouco ela vai ter 60 anos. Eu digo: "você está linda! Por que quer mexer no peito? Não precisa, seu peito tá lindo. Você quer fazer para alguém?"... "Não, é para você" ... "Já que é para mim, deixa do jeito que está". Ela não tira da cabeça, vai juntar dinheiro para fazer. Mas para mim não precisa (R 36 , esposa 56 ).

Eles não consideram que suas esposas são mais velhas do que eles, o que pode ser explicado pela ideia de jovialidade associada a características como bom-humor, alegria, otimismo, energia.

\section{ELA É SUPERIOR}

É impressionante a quantidade de características positivas atribuídas por eles às esposas. Os pesquisados ressaltam que elas são: carismáticas, generosas, carinhosas, atenciosas, dedicadas, amigas, divertidas, alegres, bem-humoradas, engraçadas, risonhas, brincalhonas, animadas, compreensivas, parceiras, companheiras, dispostas, joviais, entre inúmeras outras qualidades. Um deles ainda diz: "ela não tem defeitos. Para mim, é a mulher mais perfeita do mundo".

Eu acho que a inteligência é afrodisíaca. Minha mulher me orienta, me dá muita luz, é uma pessoa muito sábia, muito vivida, meu bálsamo. Eu descanso a cabeça em paz, seguro. A gente se dá muito bem sexualmente, nossas ideias e valores são muito parecidos ( $\mathrm{R} 36$, esposa 56 ).

O discurso masculino sobre as esposas é de permanente amor, admiração, respeito, interesse e, muitas vezes, gratidão. Elas são detentoras dos principais capitais da relação; elas são especiais justamente por serem mais velhas, experientes, maduras, seguras. Estes capitais, para eles, são muito mais importantes em uma relação amorosa do que a juventude feminina. Neste sentido, são muito superiores a qualquer outra mulher, mesmo que mais jovem e bonita. "Eu tenho medo de perdê-la, como que eu vou achar uma mulher igual?" (E 40, esposa 56).

Para eles, a juventude feminina não é um valor, mas uma ausência de valor. A juventude feminina significa cobranças, inseguranças, imaturidades, faltas, infantilidades. A mulher mais madura pode dar muito mais para eles.

A mulher mais velha é mais sensual que a novinha. A garota de 18 anos é largada, quer usar chinelo, a mais madura não, é mais arrumada, mais elegante, mais cheirosa (E 40, esposa 56). 
Ela gosta muito de me agradar. Gosta de comprar minhas roupas, fazer minha unha, botar meu pé na água. Ela gosta de botar comida no meu prato. Quando estou dormindo, ela sai na ponta do pé, não deixa ninguém fazer barulho, tira o telefone do gancho. Tem sempre a preocupação de fazer o almoço que eu gosto. Faz tudo para me agradar. Quando que uma mulher mais jovem faria isso? ( $\mathrm{R} 36$, esposa 55 ).

Até pelo fato de ela ser mais experiente, ela não força a barra. A mulher mais novinha força muito a barra (J 25, esposa 41).

\section{O DISCURSO FEMININO: ELE ME FAZ SENTIR ESPECIAL}

Ao analisar os discursos femininos, é fácil perceber que elas enfatizam o fato de se sentirem especiais para seus maridos. Elas afirmam que eles dependem delas, que eles querem sua atenção em tempo integral, que eles sentem ciúmes delas.

É muito curioso observar que os principais capitais para os homens são características relativas ao que "elas são", enquanto o discurso feminino é voltado para o que "ele me faz sentir".

As principais qualidades de seus maridos estão no fato de elas experimentarem com eles a sensação de que são especiais e superiores às demais mulheres, especialmente as mais jovens: I) Ele me faz sentir especial; 2) Ele me faz sentir jovem; 3) Ele me faz sentir segura.

\section{ELE ME FAZ SENTIR ESPECIAL}

É interessante perceber, como mostra Neves, que as pesquisadas falam muito mais de si mesmas do que dos maridos, ao contrário deles, que passam mais tempo falando dos atributos positivos delas.

Elas são muito autoelogiosas, parecendo querer justificar o interesse deles por elas, como se fosse necessário compensar sua falta de juventude com um excesso de outras qualidades.

Os elogios que fazem a si mesmas parecem funcionar como um mecanismo de compensação: o fato de serem mais velhas e, consequentemente, possuírem inúmeras qualidades que as mulheres mais jovens não têm, faz delas mulheres especiais ou mesmo "superiores". Neste sentido, poderíamos dizer que elas transformam a falta de juventude em virtude. Ou ainda, como diria Erving Goffman (1975), elas manipulam o possível estigma para produzir uma situação de superioridade.

De certa forma, usam o mesmo mecanismo autojustificativo das mulheres que são amantes de homens casados (Goldenberg, 2009). As amantes que pesquisei dizem que são superiores às esposas traídas por serem únicas e especiais para os seus homens, enfatizando que eles estão com elas por desejo e não por obrigações familiares ou sociais. Destacam a não-obrigatorie- 
dade das relações e também o fato de seus amantes escolherem estar com elas pelo prazer e companheirismo, sem dependência financeira ou de outra ordem.

As mulheres casadas com homens mais jovens também apresentam o mesmo tipo de discurso autojustificativo. "Eu acho que é questão de atitude, ser segura. Ele sabe que eu estou com ele porque eu quero, e na hora que eu não quiser, eu vou embora" (D 39, marido 28). "Na parte sensual, uma mulher na idade da gente conhece muito mais o seu próprio corpo, sabe o que quer sexualmente mais do que uma garota de 23 anos" ( $\mathrm{K}_{46} 6$, marido 35 ).

Elas enfatizam que recebem muitos elogios dos maridos:

Ele me elogia muito. Às vezes eu digo que sou cheia de defeitos. Eu faço uma comida, ele diz que está sempre delicioso, que eu não tenho defeitos, que eu não tenho celulite. Eu não fico preocupada. Às vezes eu vejo a preocupação nas pessoas que eu conheço e lembro da diferença tão gritante. Ele sempre diz: "tudo que você faz é perfeito". Eu peço para ele mostrar os meus defeitos para eu poder melhorar, mas ele diz que eu não tenho defeito (C 56, marido 36 ).

Ele sempre me elogia. Eu toda horrorosa: "você está linda, você está bonita assim mesmo". Eu me olho no espelho e vejo uma velha enrugada. "Deixa isso para lá". Ele fica ciumento, o telefone toca: "quem está ligando para você?" (G 56 , marido 34).

Como enfatizei em outros estudos (Goldenberg, 2008, 2010), a mulher brasileira quer ser a única na vida de um homem. Assim, para elas, a principal qualidade masculina seria a de conseguir fazê-las sentir que são especiais em um mercado de casamento extremamente competitivo. "Eu acho que o respeito, o amor que ele tem por mim e gostamos das mesmas coisas. Ele me admira muito e me respeita por eu ser mais segura" (M 50, marido 35).

O marido é um verdadeiro capital em um mercado matrimonial em que os homens disponíveis são escassos (Goldenberg, 20I0). A competição feminina por um marido, especialmente na faixa etária das pesquisadas, é muito grande. Elas, então, destacam a própria superioridade e valor neste mercado competitivo para justificar a escolha deles por elas, em meio a uma oferta tão grande de mulheres mais jovens.

\section{ELE ME FAZ SENTIR JOVEM}

É interessante observar como as pesquisadas fazem questão de afirmar que eles é que são mais velhos do que elas, de que eles têm "cabeça de velho", que se comportam como velhos. Elas, na verdade, são mais jovens do que eles, em termos de comportamento, personalidade e espírito.

Ele é que tem cabeça de velho, ele só gosta de coisa antiga, a começar por mim. As músicas são antigas, melancólicas, não gosta de teatro, de cinema, não gosta de sair, de ir nas casas dos outros, passear. Come todo dia bife e batata frita, não gosta de ir a restaurantes, não gosta de se divertir (G 56, marido 34). 
A idade cronológica, aqui, importa menos do que o comportamento ou espírito jovem: ativo, alegre, disponível, comunicativo, festeiro e social.

A minha situação é meio gritante, eu tenho 56, meu marido tem 36 . Mas eu acho que é temperamento, a disposição, a forma que você vê a vida. Porque lá em casa o velho é ele, porque eu quero fazer tudo, já acordo com sorriso até as orelhas, tudo para mim está bom, eu não me importo com distância, não me importo de ir em festa junina, e ele não. Ele é mais reservado, mais calado, sempre foi assim (C 56, marido 36).

\section{ELE ME FAZ SENTIR SEGURA}

Todas as pesquisadas afirmam que o relacionamento começou como uma brincadeira sem expectativas e sem compromissos. Elas não pensavam no futuro e acreditavam que o relacionamento não iria durar muito. Só queriam se divertir e aproveitar o momento. Em função da diferença de idade, elas achavam que a relação iria terminar rapidamente e que eles logo encontrariam uma namorada mais jovem. No entanto, a relação que seria passageira se tornou duradoura, sem que tenham apostado nisso.

Podemos pensar que o próprio fato de a relação ser encarada por elas como uma brincadeira acabou fortalecendo o amor e a admiração que eles sentiam por elas. Todos os pesquisados destacaram a leveza, o bom-humor e a alegria de suas esposas como qualidades fundamentais que as diferenciam das mulheres mais jovens, consideradas inseguras, controladoras, grudentas, pegajosas e infantis.

Elas afirmam que se sentem seguras com eles. Enfatizam que quem sente ciúmes é ele, não ela, demonstrando que a insegurança maior é deles.

Nós não brigamos, não existe problema de infidelidade. No dia que a idade bater nós vamos sentar e conversar, nós vamos viver um dia de cada vez. Não bate insegurança. Se uma mulher olhar para ele, eu tenho ciúme, mas eu olho para ela, vejo se ela está com tudo em cima para fazer a comparação que todas nós mulheres fazemos. Se estiver, eu pego o meu biscoitinho e vou embora para casa. Eu tinha ciúmes das pessoas que eu namorei quando era mais jovem, não dele (C 56, marido 36).

Eu não tenho ciúmes dele, mas ele tem muito ciúmes de mim. Quando eu estou trabalhando, eu ligo para ele: "vai para a praia, vai ver bunda". Ele diz: "não, eu não quero, eu quero ficar em casa, eu vejo a sua quando você chegar". Ele é ótimo comigo, parceiro. Eu trabalho de manhã e ele de tarde, ele fica em casa e lava a roupa, arruma a casa, limpa vidro, aí fala: "já fiz tudo para você chegar em casa e ver televisão, não vai para a rua. Me espera que de noite eu vou te dar um pega" (G 56, marido 34).

Elas dizem que eles são carentes e sentem ciúmes da atenção que elas dedicam aos outros: filhos, netos, amigos, familiares etc. Eles querem ser o centro da atenção delas. 
Meu marido tem a idade dos meus filhos. A princípio não acreditaram, ninguém acredita. Se me contarem que tem uma mulher de $56 \mathrm{com}$ um marido de $36 \ldots$ Mas eu não me importo, a gente tem que ser feliz, ninguém pode ser infeliz para agradar o outro. Mas rola ciúmes. Ele tem muito ciúmes da atenção que dou para os meus filhos e netos. Implicâncias juvenis. Ele compete com eles. Quer atenção, carinho e cuidado só para ele. Se faço uma comidinha especial para os meus filhos, tenho que fazer para ele também. Parece criança mimada (C 56, marido 36).

Ele gosta de se sentir importante, de eu dar atenção, e eu não vejo como uma necessidade maternal, de conforto, porque às vezes a necessidade da mulher é como mãe, a fazedora de chazinho, da comidinha na mesa, mas ele gosta dessa importância, do paparico, de elogio. Ele exige muito mais de mim do que eu exijo dele (G 56, marido 34 ).

\section{O INFERNO SÃO AS OUTRAS}

Para as pesquisadas, o olhar dos outros sobre o casal é motivo de constrangimento e de vergonha. Eles parecem não se incomodar com o que os outros pensam e nem mesmo enxergar este tipo de olhar. É como se elas estivessem muito mais vulneráveis e atentas ao menor sinal de desaprovação social.

Quando vamos ao supermercado, as mulheres ficam olhando como se fosse coisa do outro mundo. Eu fico com vergonha, e ele é muito carinhoso, elas ficam olhando e eu não sei onde eu enfio a cara (D 50, marido 32).

Eu tinha vergonha de dar beijinho na rua, me sentia mal, como se eu estivesse fazendo algo terrível, errado. Ele me abraçava e eu sentia que era como se fosse o meu filho, eu não queria me sentir dessa forma, no meio da rua. Mas era puro preconceito (V 49, marido 39).

As pesquisadas acreditam que os outros pensam que elas sustentam os maridos, o que pode parecer a única razão masculina para o casamento. Parece existir, por parte delas, a necessidade de justificar o casamento por outros motivos "mais nobres".

Eu tenho a impressão de que quando eu passava com ele os vizinhos pensavam assim: "ela deve ganhar bem mais que ele, ela está sustentando ele" (V 49, marido 39).

Por mais que ele trabalhe, sempre dá a impressão que eu é que sustento. Por ser mais velha, parece que tenho mais dinheiro. Os outros acham que eu sustento. Mas ele tem o trabalho dele e ganha mais do que eu (D 50, marido 32).

As amigas delas também demonstraram preocupações e preconceitos com relação ao fato de as pesquisadas casarem com homens mais jovens.

Eu já ouvi isso claramente, na época em que ele fazia a faculdade, que quem bancava a casa era eu. Eu ouvia da minha própria mãe e das minhas amigas que ele estava comigo só por interesse, que não era nada sério (L 38, marido 28). 
"Está vendo! Ele acha que você tem dinheiro, porque você mora no Leme, que você vai sustentar!". Isso é o que mais acontece, as pessoas pensam assim mesmo. Até mesmo minhas amigas. Diziam que eu merecia uma coisa melhor, algumas até deixaram de falar comigo (F 51, marido 41).

Elas relatam inúmeras situações em que o marido é confundido com um filho. "Eu saía, e os outros, eu ficava com vergonha, perguntavam se era meu filho. Às vezes eu dizia que era" (G 56, marido 34).

Nesse confronto com o olhar do outro, são eles os responsáveis por impor o papel de marido, parecendo se importar menos com o julgamento alheio.

Pela idade, eu sempre chamava de meu filho. Ele reagia: "eu não sou seu filho, que mania! Eu sou seu marido, você tem que me tratar como seu marido, não como filho. Você não tem que dizer que eu sou seu filho, eu sou seu marido". Daí para cá eu fui perdendo o medo (G 56, marido 34).

Talvez os homens brasileiros se importem menos com os julgamentos alheios do que as mulheres, das quais se espera, como disse Pierre Bourdieu (20I0), que sejam submissas, discretas, contidas, constituindo-se em objetos simbólicos, cujo ser existe pelo e para o olhar dos outros. Para o autor, a dignidade da mulher está, em parte, confirmada pelo fato de que o homem ocupa, pelo menos aparentemente, a posição dominante no casal, o que inclui a idade superior.

As pesquisadas revelam que os maiores obstáculos para a relação vieram das mães delas e das sogras. As filhas, da mesma idade de seus atuais maridos, em muitos casos, provocaram muitas brigas e situações difíceis, especialmente no início do relacionamento.

Minha filha no início foi contra: "mãe você é doida, não vê que ele é muito novo?". "Eu estou só namorando". Ela ainda resistiu um pouco, aquelas coisas de filha (V 49, marido 39).

Minha filha tem 33 anos e ele tem 32. Quando ela conheceu: "seu filho?". Eu disse: "eu não tenho filhos homens" (D 50, marido 32).

Como afirmou Neves, as mães delas poderiam acreditar que elas poderiam ser magoadas, pois os homens mais jovens só iriam querer transar, se divertir e depois ir embora.

Até hoje minha mãe fala: "Você é bem mais velha que ele, isso aí é só casual". Eu sempre coloquei ela no lugar dela: "você teve a sua história, lamento se você quis ter a vidinha do crochê, eu hoje não tenho mais, eu quero ser feliz até o último momento da minha vida" (A 48, marido 33).

Neves sugere que os conselhos dados pelas mães às pesquisadas pressupõem que o homem é aquele que se diverte e a mulher aquela que se prejudica. Portanto, a diversão seria algo não igualitário entre os gêneros no âmbito de relações amorosas e sexuais. 
Minha mãe dizia que ele só queria brincar, mas eu também só queria brincar. Eu não queria relação séria, eu conheci ele na noite. "Eu vou dar uns pegas nesse cara, depois eu não vou ver ele nunca mais mesmo". Só que eu acho que ele gostou dos pegas, a gente foi saindo e está aí até hoje ( $\mathrm{K} 46$, marido 35 ).

"Você está muito velha para ele! Você não tem vergonha?" No fundo, eu tinha, vergonha e medo. Todo mundo falava: "garoto novo, você acha que ele vai querer alguma coisa com você? Ele vai querer vida boa" (G 56, marido 34).

Minha mãe dizia o tempo todo: "você é bem mais velha do que ele, isso aí é só casual. Ele não vai levar a sério, nunca”. (A 48, marido 33)

As sogras delas, mães deles, também foram obstáculos a serem superados.

Eu me dou muito melhor com o pai dele do que com a mãe. O pai dele sempre me tratou bem, mas a mãe sempre dizia: "meu filho vai ter que me dar um neto", sempre provocando ( $\mathrm{G} 56$, marido 34 ).

O mais difícil foi convencer a mãe dele que ele iria ficar com uma mulher mais velha que não pode mais ter filhos. A mãe dele falava: "como você pode ficar com ela, ela não pode ter filhos". Amanhã ele pode pensar: "eu passei pela vida e não deixei nenhum fruto, não tenho nenhum filho". Tenho medo de ele querer ter filho. Eu quis adotar uma criança, mas ele falou: "nós temos as suas netas, não vejo necessidade disso" (V 49, marido 39).

A mãe dele teve muita resistência: "uma mulher mais velha, o que ela quer com o meu bebê?". Ainda mais que ele fazia faculdade. Eu não me deixo levar muito pelo que falam, eu penso muito mais comigo mesma. No começo eram piadas, por exemplo, que eu tinha que usar botox antes da hora. A mãe dele não é muito mais velha que eu. Ela tem 47 anos, uma mulher jovem também. É separada do marido e depositava todos os sonhos no filho, e de repente eu fui lá e peguei. Ela veio com a história do botox, como quem diz: "meu filho vai parecer jovem mais tempo e você vai aparentar ser velha". Eu falei: "mas eu nunca vou usar botox, porque beleza acaba". Ela viu que eu não estava de brincadeira com ele e ele também não estava comigo (L 38, marido 28).

Neves levanta a hipótese de que os mais próximos têm coragem para dizer o que pensam, e para externar o que há de mais cruel no imaginário social. Para a autora, uma segunda hipótese consistiria em enxergar tais advertências como preocupação em evitar o sofrimento delas, tendo em conta a realidade dos julgamentos sociais. As mulheres das famílias delas e deles parecem concretizar as representações negativas mais gerais sobre o relacionamento entre homens mais novos e mulheres mais velhas.

Como afirma Howard Becker (I966), não há razão para supor que somente aqueles que realizam um ato desviante tenham o impulso ou o desejo de fazê-lo. Para ele, é muito provável que muitos indivíduos tenham o desejo de realizar comportamentos desviantes. Pelo menos na fantasia, todos somos muito mais desviantes do que parecemos.

O autor acredita que em vez de perguntar por que os que são vistos como desviantes querem fazer coisas que são proibidas, deveríamos pergun- 
tar por que a maioria das pessoas não concretiza seus desejos desviantes.

Para Becker, os grupos sociais criam o desvio ao fazer as regras e ao aplicar essas regras a pessoas particulares, rotulando-as de marginais ou desviantes. Portanto, o desvio não é uma qualidade do ato que a pessoa comete, mas uma consequência da aplicação por outras pessoas de regras e sanções a um transgressor. O comportamento desviante é aquele que os outros rotulam como tal.

É possível perceber, nos casais estudados, que as mulheres internalizam as acusações de desvio, sentindo constrangimento e vergonha, ou criando obstáculos para a concretização dos casamentos em que elas são mais velhas que os maridos.

No discurso masculino não aparece a internalização das acusações de desvio. Eles não falam de vergonha ou constrangimento. Eles não criam obstáculos. Eles podem até se perceber como diferentes da maioria dos homens, mas não como desviantes. A diferença é vista por eles como algo positivo, pois acreditam que estão casados com mulheres muito especiais e superiores à maioria das mulheres. É uma diferença distintiva, um traço de superioridade, um motivo de orgulho, não de vergonha.

Interessante destacar que o maior preconceito com relação a este tipo de casamento vem, justamente, das mulheres. Como é percebido nos depoimentos, são as próprias mulheres as mais contrárias a este arranjo conjugal, não os homens. São elas que ficam mais inseguras, envergonhadas ou constrangidas por casarem com um homem mais jovem e são elas, também, as que colocam mais obstáculos.

Esta realidade sugere que o tabu da idade é algo, fundamentalmente, feminino. São as mulheres que demonstram muito mais impedimento e preocupação com o fato de serem mais velhas que os maridos. Apesar de serem as que mais sofrem com os preconceitos e acusações, são elas que mais resistem a destruir o tabu da idade.

\section{RECIPROCIDADE + RECONHECIMENTO: O SEGREDO DO CASAMENTO FELIZ}

Já mostrei em outros estudos (Goldenberg, 2008, 2010) que as mulheres se queixam muito de seus parceiros e afirmam que gostariam que eles fossem mais atenciosos, românticos, disponíveis, respeitosos, fizessem mais elogios etc. Por outro lado, os homens gostariam que suas parceiras fossem menos chatas, ciumentas, pegajosas, dependentes, exigentes, perfeccionistas etc.

Os casais estudados, ao inverterem a lógica da dominação masculina, que, como afirma Bourdieu (20I0), exige que os homens sejam superiores às mulheres em idade e em outros atributos (como poder, prestígio, dinheiro etc.), parecem encontrar uma lógica compensatória. 
As mulheres têm mais idade, mas são consideradas menos chatas, menos infantis, menos ciumentas, menos pesadas, menos "reclamonas", menos pegajosas, menos inseguras, menos grudentas etc. Os homens têm menos idade, mas são mais atenciosos, mais românticos, mais carinhosos, mais dedicados, mais fiéis etc.

O que é possível perceber nos depoimentos analisados é que o valor da mulher nos seus casamentos parece estar em outras qualidades e não no corpo jovem. Seus capitais principais são a capacidade de ensinar algo, de mudar a visão de mundo, de orientar, além do cuidado, companheirismo, carinho, atenção e compreensão. São mulheres carismáticas, bem-humoradas, alegres, joviais, consideradas extremamente generosas e disponíveis para os maridos, mas também para os familiares e amigos.

Por mais estranho que possa parecer, apesar de este tipo de relação ser considerada desigual, encontrei uma situação bastante equilibrada para os homens e mulheres pesquisados. Aparentemente, elas são percebidas como dando muito mais do que eles, em termos de posição social, maturidade, experiência, cuidado, carinho, atenção etc. No entanto, eles dão aquilo que as mulheres brasileiras mais desejam: a sensação de serem únicas e especiais. Elas recebem elogios, admiração e a prova constante de sua superioridade em relação às mulheres mais jovens.

Eles usam recorrentemente a ideia de "salvação" para justificar o amor por elas. Especialmente no início da relação, eles dizem que elas "salvaram" suas vidas, no sentido de guiá-los para um caminho melhor, de cuidar deles, de ajudá-los a se afastar das drogas e das más companhias. Muitos disseram que, antes delas, "estavam perdidos no mundo". Por outro lado, a mesma ideia de "salvação" pode ser aplicada a elas: eles as salvaram da invisibilidade em um mercado afetivo e sexual que valoriza a juventude feminina.

"Salvação" é uma palavra interessante para pensar o discurso masculino e feminino. Elas "salvaram" seus maridos das drogas, das más companhias, da bebida e, talvez, da morte precoce. Elas viram neles a possibilidade de serem pessoas melhores, estudarem, trabalharem, terem uma vida familiar e feliz. Elas enxergaram neles o que era invisível para eles mesmos e para os outros. Eles são gratos por este reconhecimento.

Já eles as "salvaram" da invisibilidade social. Enxergaram nelas mulheres superiores em sua essência, não valorizando a aparência jovem. Eles mostraram que para um bom relacionamento outros valores e atributos são muito mais importantes. Eles, também, enxergaram nelas o que é invisível e desvalorizado pelos outros, e, em muitos casos, por elas mesmas. Eles as "salvaram" da "morte simbólica" ou da "morte social". Elas são gratas por este reconhecimento. E ambos "salvaram" seus casamentos da rotina, do desgaste, da "mesmice", da acomodação, da "morte" do amor, do fim da admiração. Ambos se sentem plenamente satisfeitos e reconhecidos. 
Um relacionamento que precisa enfrentar o tabu da idade, que necessita superar os obstáculos familiares e vencer inseguranças, preconceitos e acusações parece ser muito mais satisfatório do que relacionamentos mais aceitos socialmente. Os dois, homem e mulher, procuram ser o seu melhor com o cônjuge, e não o seu pior, como ocorre em muitos casamentos por mim pesquisados (Goldenberg, 2008). Eles não têm a mesma sensação de segurança e de estabilidade que provoca, em muitos casamentos, o desgaste pela rotina, "mesmice", acomodação. Os dois precisam "batalhar" muito mais do que os casais convencionais para ficarem juntos.

Em um mercado afetivo e sexual extremamente desvantajoso para as mulheres, especialmente para aquelas da faixa etária das pesquisadas, ter um marido apaixonado e fiel é motivo de satisfação. O marido, neste caso, é um capital ainda mais valorizado por escolher uma mulher mais velha, quando teria muitas possibilidades de escolher esposas mais jovens no mercado matrimonial.

As pesquisadas se sentem duplamente poderosas: por terem o capital marital e, também, por serem consideradas mais interessantes e desejáveis que as mulheres mais jovens. Mais ainda, em uma cultura em que o corpo é um capital, elas sentem que não perderam o valor por terem envelhecido. Ao contrário, sentem que ganharam amor, admiração e reconhecimento por outros capitais que acumularam durante suas vidas.

Como afirmou Elza Berquó (I998), são muito raros os estudos sobre outras moedas de troca, além da juventude, oferecidas pelas mulheres e aceitas pelos homens no mercado matrimonial.

Espero ter contribuído para pensar nas muitas outras moedas de troca extremamente valiosas nas relações afetivas e sexuais contemporâneas. Acredito que é possível, por meio dos casos estudados, afirmar que, para muitos homens brasileiros, o principal capital para um casamento feliz é algo que só pode ser encontrado em uma mulher mais velha. No entanto, muitas mulheres não reconhecem o valor da própria experiência, maturidade e de tudo o que conquistaram ao longo de suas vidas e sofrem excessivamente com a passagem do tempo.

Ao constatar a satisfação dos casais pesquisados, descobri que, em vez de perguntar por que determinados homens se casam com mulheres mais velhas, deveria questionar os motivos que levam a maioria dos homens brasileiros a continuar preferindo se casar com mulheres mais jovens. E, também, deveria questionar as razões que levam grande parte das mulheres brasileiras a aceitar e fortalecer, com seus medos, inseguranças e preconceitos, o tabu da idade. 
Mirian Goldenberg é doutora em Antropologia Social pelo Programa de Pós-Graduação em Antropologia Social da Universidade Federal do Rio de Janeiro (PPGAS-UFRJ) e professora do Programa de Pós-Graduação em Sociologia e Antropologia da mesma universidade (PPGSA-UFRJ). Suas áreas de interesse são: gênero, corpo, envelhecimento, sexualidade e conjugalidade. É colunista do jornal Folha de S. Paulo desde 20io. Publicou vários livros, entre eles: A arte de pesquisar (1997); Toda mulher é meio Leila Diniz (2008); Por que homens e mulheres traem? (2010); e A bela velhice (2013). 


\section{NOTAS}

* Agradeço a colaboração de Diana Neves para minhas reflexões sobre os casamentos de mulheres mais velhas com homens mais jovens. Seu artigo "O tabu da idade e os papéis de gênero nas relações conjugais", trabalho de conclusão da disciplina Corpo, envelhecimento e felicidade, ministrada por mim no Programa de Pós-Graduação em Sociologia e Antropologia da Universidade Federal do Rio de Janeiro (PPGSA-UFRJ), em 20II, foi uma referência fundamental para a elaboração deste texto.

I “A apresentadora Ana Maria Braga, 63, é casada desde março de 2007 com Marcelo Frisoni, 40. A diferença de idade não importa para ela. 'Eu já tive tanto homem mais velho do que eu e acabei separando deles do mesmo jeito. Não é porque era mais velho ou mais novo que a gente ficou junto'”. (A Tribuna, Vitória, ES, Io/03/2013).

2 “Aos 70 anos, a atriz Susana Vieira está noiva de Sandro Pedroso, 29, 4I anos mais jovem do que ela. Eles estão juntos desde 2009. Ela disse que não liga para a diferença de idade de seus parceiros amorosos. 'Não fico procurando garotão em porta de universidade, mas não tenho culpa se sou desejada por jovens. Sou uma estrela. Não estou nem aí para preconceitos. Aliás, idade não existe para mim', comentou a atriz". (A Tribuna, Vitória, ES, Iо/03/2013).

3 Disponível em: <http://mariliapera.no.comunidades.net/ index.php? pagina $=\mathrm{I} 230984734>$.

\section{REFERÊNCIAS BIBLIOGRÁFICAS}

Becker, Howard. (1966). Outsiders: studies in the sociology of deviance. Nova York: The Free Press.

Berquó, Elza. (1998). Arranjos familiares no Brasil: uma visão demográfica. In: Schwarcz, Lilia M. (org.). História da vida privada no Brasil: contrastes da intimidade contemporânea. São Paulo: Companhia das Letras, p. 4II-437.

Bourdieu, Pierre. (20I0). A dominação masculina. Rio de Janeiro: Bertrand Brasil.

Bourdieu, Pierre. (2007). A distinção. São Paulo: Edusp.

Goffman, Erving. (1975). Estigma: notas sobre a manipulação da identidade deteriorada. Rio de Janeiro: Zahar. 
Goldenberg, Mirian. (20I3). A bela velhice. Rio de Janeiro: Record.

Goldenberg, Mirian. (20II). Corpo, envelhecimento e felicidade. Rio de Janeiro: Civilização Brasileira.

Goldenberg, Mirian. (2010). Intimidade. Rio de Janeiro: Record.

Goldenberg, Mirian. (2009). A outra. Rio de Janeiro: BestBolso.

Goldenberg, Mirian. (2008). Coroas: corpo, envelhecimento e felicidade. Rio de Janeiro: Record.

Goldenberg, Mirian. (2007). O corpo como capital. São Paulo: Estação das Letras e Cores.

Goldenberg, Mirian. (2002). Nu \& vestido. Rio de Janeiro: Record.

Mauss, Marcel. (1974). As técnicas corporais. In: Sociologia e antropologia. São Paulo: EPU/Edusp.

Neves, Diana. (20II). O tabu da idade e os papéis de gênero nas relações conjugais. Trabalho final da disciplina Corpo, envelhecimento e felicidade, ministrada por Mirian Goldenberg no Programa de Pós-Graduação em Sociologia e Antropologia da Universidade Federal do Rio de Janeiro (PPGSA-UFRJ). 


\section{CASAMENTOS INVERTIDOS: ACUSAÇÕES E PRECONCEITOS EM ARRANJOS CONJUGAIS DESVIANTES}

Resumo

Por que determinados homens se casam com mulheres mais velhas? Por que algumas mulheres escolhem homens mais jovens? Quais são os principais capitais desses arranjos conjugais? Este artigo busca analisar os discursos femininos e masculinos sobre casamentos nos quais as mulheres são mais velhas do que seus maridos. Utilizo como base para reflexão os dados da pesquisa "Corpo, envelhecimento e felicidade". São analisados os resultados de dois grupos focais: o primeiro com doze mulheres casadas com homens mais novos, o segundo com dez homens casados com mulheres mais velhas. Após os grupos, foram realizadas nove entrevistas em profundidade, cinco com homens e quatro com mulheres. Trabalhei com casais que estão juntos há pelo menos dez anos. Elas são, pelo menos, dez anos mais velhas do que seus maridos.

\section{INVERTED WEDDINGS: ACCUSATIONS AND PREJUDICES IN DEVIANT MARITAL ARRANGEMENTS} older than their husbands, using survey data from my research "Body, aging and happiness". The results of two focus groups are analyzed: the first with twelve women married to younger men, the second with ten men married to older women. The results of nine in-depth interviews, five with men and four with women, are also examined. I worked with couples that have been together for at least ten years. The women are at least ten years older than their husbands.
Palavras-chave

Gênero;

Corpo;

Envelhecimento;

Casamento;

Família.
Keywords

Gender;

Body;

Aging;

Marriage;

Family. 